\title{
Using pregnancy-associated glycoproteins to provide early pregnancy diagnosis in Nelore cows
}

\author{
Gláucia Mota Bragança ${ }^{\mathrm{a}}$, Bruno Moura Monteiro ${ }^{\mathrm{b}}$, Rodrigo dos Santos Albuquerque ${ }^{\mathrm{c}, *}$, \\ Damazio Campos de Souza ${ }^{\mathrm{d}}$, Claudio Cabral Campello ${ }^{\mathrm{e}}$, Silvia Oliveira Zimmerman ${ }^{\mathrm{f}}$, \\ Waldjânio de Oliveira Melo ${ }^{\mathrm{b}}$, Pedro Paulo Maia Teixeira ${ }^{\mathrm{c}}$, José Dantas Ribeiro Filho ${ }^{\mathrm{g}}$, \\ Rinaldo Batista Viana ${ }^{\text {h }}$
}

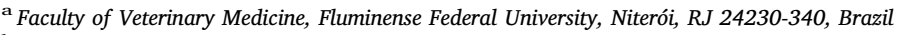

${ }^{\mathrm{b}}$ Federal Rural University of Amazon, 68625-970 Paragominas, PA, Brazil

${ }^{\mathrm{c}}$ Institute of Veterinary Medicine, Federal University of Pará, 68740-970 Castanhal, PA, Brazil

d Department of Clinical and Veterinary Surgery, Paulista State University "Júlio de Mesquita Filho", Jaboticabal, SP 14884-900, Brazil

${ }^{\mathrm{e}}$ Faculty of Veterinary Medicine, State University of Ceará, Fortaleza, CE 6077-901, Brazil

${ }^{\mathrm{f}}$ Latin America Area Manager, IDEXX Livestock and Poultry Diagnostics One IDEXX Drive, Westbrook, ME 04092, USA

${ }^{g}$ Department of Veterinary Medicine, Federal University of Viçosa, Viçosa, MG 36571-000, Brazil

${ }^{\mathrm{h}}$ Institute of Animal Health and Production, Federal Rural University of Amazon, Belém, PA 6077-901, Brazil

\section{A R T I C L E I N F O}

\section{Keywords:}

Pregnancy detection

Beef cattle

Pregnancy-associated glycoproteins

ELISA

\begin{abstract}
A B S T R A C T
Pregnancy-associated glycoproteins (PAG) are expressed in the placenta of ungulate mammals. Ruminants secrete PAGs continuously from embryonic implantation until delivery. In this study, we evaluated the feasibility of using ELISA to detect PAG levels as a method for early pregnancy diagnosis in Zebu (Nelore) beef cows. We compared the efficacy of this method with transrectal ultrasonography (US) in detecting pregnancy on the 25th and 28th days after timed artificial insemination (TAI) of 130 crossbred Zebu cows. Blood samples were taken during these two time points for PAG determination; ultrasound examinations were also performed on both days. Rectal palpation was used on the 80th day to definitively verify pregnancy. PAG ELISA accuracy was equal across both time points, with $100 \%$ sensitivity, $92.86 \%$ specificity, $96.70 \%$ positive predictive value, and $100 \%$ negative predictive value. In contrast, US had $62.50 \%$ and $93.18 \%$ sensitivity, $95.24 \%$ specificity, $96.49 \%$ and $97.63 \%$ positive predictive value, coupled with $54.79 \%$ and $86.96 \%$ negative predictive value on the 25 th and 28th days, respectively. Thus, the two diagnosis methods differed significantly in negative predictive value and sensitivity, but not positive predictive value or specificity. In conclusion, PAG ELISA was just as specific as US, but more sensitive. Its safety (compared with US and rectal palpation) and high accuracy in identifying nonpregnant cows make PAG ELISA a good option for early pregnancy diagnosis (beginning 25 days post-TAI) in Zebu females.
\end{abstract}

\section{Introduction}

Early pregnancy detection is useful for increasing cattle reproductive efficiency. Non-pregnant cows can be identified quickly after the final service rates, minimizing economic losses that occur if pregnant cows are erroneously culled or non-pregnant cows are retained. Furthermore, service rates can be indirectly increased through lower birth-conception or between-birth intervals (Green et al., 2011; Ribeiro et al., 2012).

For optimal identification of early pregnancies, were require effective diagnostic methods that are accurate, practical, rapid, and cost- effective (Karen et al., 2015). To that end, an increasingly popular technique for diagnosing gestation is quantifying pregnancy-associated glycoproteins (PAG), inactive aspartic proteases in the trophoblasts of placental binucleated cells. From day 24 post-fertilization, PAGs are released into the maternal bloodstream, becoming an important marker of pregnancy and fetal viability (Wallace et al., 2015). The use of PAG quantification were positively correlated with normal pregnancies being important indicator of fetal viability (Dobson et al., 1993).

Existing PAG analyses of dairy and beef cattle (Ricci et al., 2015; Roberts et al., 2015) have typically focused on taurine cows (Bos taurus taurus) (Commun et al., 2016; Shahin et al., 2014). These studies report

\footnotetext{
* Corresponding author

E-mail address: rdsa20@gmail.com (R.d.S. Albuquerque).
} 
that $B$. taurus indicus have higher PAG concentration during gestation (between 32 and 62 days post-insemination) than B. taurus taurus, suggesting a genetic influence on protein profiles. Thus, such techniques for gestational diagnoses must be specifically validated in Zebu breeds to enhance their effectiveness and broaden their applicability (Mercadante et al., 2013).

With this objective in mind, here we evaluated the viability of a commercial ELISA kit in detecting PAG concentrations of Nelore cows at 25 and 28 days post-insemination. We also aimed to compare the effectiveness of the PAG ELISA technique with standard methods for early pregnancy diagnosis, including ultrasound and transrectal palpation.

\section{Materials and methods}

\subsection{Study site}

The present study was conducted on a farm located in the municipality of São Francisco do Pará (located at kilometer 14 of the PA-320 highway - $01^{\circ} 10^{\prime} 15^{\prime \prime}$ South, $47^{\circ} 47^{\prime} 38^{\prime \prime}$ West), in the Brazilian state of Pará, Amazonia.

Subject females were raised with the other animals of the farm during their reproductive phase. All animals were fed exclusively in cultivated pastures of Urochloa humidicola, U. brizanta 'Marandu', and Megathyrsus maximus, with ad libitum mineral supplementation and water. Animals were vermifugated soon after birth, then subsequently in 6-month intervals, concomitant with vaccinations against foot-andmouth disease, symptomatic carbuncle, rabies, and brucellosis.

\subsection{Experimental set-up}

A three-management timed artificial insemination (TAI) protocol was applied to 130 healthy Zebu Nelore females (B. taurus indicus) with a mean body condition score of 3.5 (scale of 1 to 5) (Ayres et al., 2009). On day 0, one gram of progesterone (DIB ${ }^{\circledR}$, MSD Saúde Animal, São Paulo, Brazil) was delivered using an intravaginal device for $8 \mathrm{~d}$. Additionally, still on day 0 , a $2.0 \mathrm{mg}$ intramuscular injection of estradiol benzoate (EB) (Estrogin ${ }^{\circledR}$, Farmavet, São Paulo, Brazil) was applied. On the afternoon of day 8 , subjects were treated a second time with the same dosage of EB (1.0 mg im), along with $0.15 \mathrm{mg}$ D-cloprostenol (Preloban $^{\circledR}$, Intervet, Boxmeer, Netherlands) and $300 \mathrm{IU}$ of equine chorionic gonadotrophin (Folligon ${ }^{\circledR}$, MSD Saúde Animal, São Paulo, Brazil). Cows were artificially inseminated in the morning of day 10 (Sá Filho et al., 2011).

All females subjected to TAI protocol had a postpartum period of at least 35 days.

\subsection{Determination of PAG concentrations}

Blood samples $(10 \mathrm{~mL})$ were collected from all subjects on days 25 and 28 post-TAI, via puncturing the external jugular vein and using siliconized vacutainer tubes without anticoagulant. Samples were centrifuged for $15 \mathrm{~min}$ at $1150 \mathrm{~g}$. The supernatant was stored in cryotubes at $-20^{\circ} \mathrm{C}$ until needed for PAG determination.

Pregnancy-associated glycoprotein concentration in bovine serum was determined following manufacturer protocol from the "Bovine Pregnancy Test" ELISA kit (IDEXX Laboratories, Westbrook, Maine, USA). Analyses were performed in the Virology Laboratory of the Environment Section at Evandro Chagas Institute.

\subsection{Transrectal ultrasonography (US)}

Ultrasound (US) examinations were performed on days 25 and 28 post-TAI, using a $7.5 \mathrm{MHz}$ linear array transducer (Mindray DP 6900, Shenzhen, China). The observation of allantoic fluid or a visible fetus yielded a positive gestation diagnosis (Szenci et al., 1995). The same veterinarian conducted all US evaluations.

\subsection{Transrectal palpation}

Transrectal palpation was the method chosen as the gold standard for subsequent confirmation of pregnancy. All cows were palpated at 80 days post-TAI by an experienced technician.

\subsection{Statistical analysis}

Accuracy is defined as the proportion of pregnant and nonpregnant cows correctly identified by the test [(true positive + true negative)/ total population]. Results were classified as correct positive diagnosis (a), incorrect positive diagnosis (b), correct negative diagnosis (c), and incorrect negative diagnosis (d). Following published methods (Karen et al., 2011), sensitivity $(100 \times \mathrm{a} / \mathrm{a}+\mathrm{d})$, specificity $(100 \times \mathrm{c} /$ $c+b)$, positive predictive value (PPV) $(100 \times a / a+b)$, and negative predictive value (NPV) $(100 \times \mathrm{c} / \mathrm{c}+\mathrm{d})$ were calculated for each diagnostic method (PAG ELISA, US, palpation). A chi-square test determined significant differences in sensitivity/specificity between PAG ELISA and US. Differences between pregnant and non-pregnant cows determined via PAG ELISA were analyzed with the Student's $t$-test. Significance was set to $\mathrm{P}<0.05$.

\section{Results}

Rectal palpation 80 days post-TAI indicated that $67.69 \%(88 / 130)$ of subject cows were pregnant and $32.31 \%(42 / 130)$ were not. As shown in Table 1, the PAG ELISA test yielded three false positives, while US yielded two. No false negatives occurred under the PAG ELISA test. In contrast, considering only pregnant animals (88 cows), US identified as non-pregnant at 25 and 28 days post-TAI, respectively, $37.5 \%(33 / 88)$ and $6.8 \%(6 / 88)$.

The PAG ELISA test was equally accurate at 25 and 28 days postTAI, reaching $100 \%$ sensitivity and $92.86 \%$ specificity. Ultrasound pregnancy detection was more accurate at 28 days post-TAI (sensitivity $=93.18 \%$ and specificity $=95.24 \%$ ) than at 25 days (sensitivity $=62.50 \%$ and specificity $=95.24 \%$ ) (Table 1$)$.

The two tests did not significantly differ in specificity and PPV. However, PAG ELISA reached $100 \%$ negative predictive value at both evaluated time points, whereas US values were lower (day $25-54.79 \%$; day $28-86.96 \%$ ).

Table 1

Comparison of the results of the early diagnosis of pregnancy in Zebu cows using the PAG ELISA and transrectal ultrasonography (US) methods in relation to transrectal palpation.

\begin{tabular}{|c|c|c|c|c|c|}
\hline \multirow[t]{2}{*}{ Variables } & \multicolumn{2}{|c|}{25 days } & \multicolumn{2}{|c|}{28 days } & \multirow{2}{*}{$\begin{array}{l}80 \text { days } \\
\text { Transrectal } \\
\text { Palpation }\end{array}$} \\
\hline & PAG & US & PAG & US & \\
\hline $\begin{array}{l}\text { Correct positive } \\
\text { results }\end{array}$ & 88 & 55 & 88 & 82 & 88 \\
\hline False positives & 3 & 2 & 3 & 2 & 0 \\
\hline $\begin{array}{l}\text { Correct negative } \\
\text { results }\end{array}$ & 39 & 40 & 39 & 40 & 42 \\
\hline False negatives & 0 & 33 & 0 & 6 & 0 \\
\hline Sensitivity, \% & $100^{\mathrm{Aa}}$ & $62.50^{\mathrm{Bb}}$ & $100^{\mathrm{Aa}}$ & $93.18^{\mathrm{Ab}}$ & - \\
\hline Specificity, \% & 92.86 & 95.24 & 92.86 & 95.24 & - \\
\hline PPV, \% & 96.70 & 96.49 & 96.70 & 97.62 & - \\
\hline NPV, \% & $100^{\mathrm{Aa}}$ & $54.79^{\mathrm{Bb}}$ & $100^{\mathrm{Aa}}$ & $86.96^{\mathrm{Ab}}$ & - \\
\hline
\end{tabular}

Different uppercase letters represent significant differences between days $(\mathrm{P}<0.05)$.

Different lowercase letters represent significant differences between methods $(\mathrm{P}<0.05)$.

PPV: positive predictive value; NPV: negative predictive value. 


\section{Discussion}

In this study, we demonstrated that using a commercial ELISA test to detect serum PAG concentrations was a highly accurate form of early pregnancy diagnosis in Bos indicus beef cattle. Our results are consistent with recent research examining the effectiveness of such tests in dairy taurine cows (Karen et al., 2015; Ricci et al., 2015). Specifically, PAG ELISA was $100 \%$ accurate in categorizing pregnant cows based on day 25 blood samples, compared with 93.9\% (Romano and Larson, 2010), 94.6\% (Sinedino et al., 2014), and 96.8\% (Silva et al., 2007) sensitivity at 28 days post-TAI using the same test in taurine cows. Minor variations in these results are likely due to the fact that Zebu cows have higher baseline PAG concentrations than taurine cows (Mercadante et al., 2013). Because breed, fetus number, and fetus genotype can all influence PAG levels (de Sousa et al., 2003), these factors must be accounted during any cross-breed comparisons. Indeed, interspecific differences in gestational period could also lead to variation when PAG is detectable in the cow (Garbayo et al., 2008).

Several previous studies (Real et al., 2006; Romano et al., 2006) using fetal heartbeat detection with US also observed low sensitivity on day 25 post-TAI, similar to our findings. This lower diagnostic accuracy can be explained by difficulties in visualizing the gestational vesicle, along with ambiguities in interpreting image from early pregnancy. Specifically, the allantoic fluid can be confused with pathological or physiological fluids, and the gestational vesicle can only be clearly observed after 28 days of gestation (Barros and Visintin, 2001). In contrast, the high accuracy of PAG ELISA is related to the proteins' immunoreactivity across pregnancy. While PAGs are detectable from day 22, immunoreactivity increases considerably during days 24-28 and continues to rise until the last week of pregnancy. Thus, gestation diagnoses using PAG concentrations are the most accurate during this period (Green et al., 2005).

PAG ELISA and US specificity did not differ significantly. Our results corroborated previous findings using the same comparison method of $91.7 \pm 1.4 \%$ specificity in dairy cattle between $25-45$ days of gestation and $92.3 \pm 3.0 \%$ specificity in beef cattle $(92.3 \pm 3.0 \%)$ between 29-56 days of gestation (Green et al., 2009). Further, diagnoses using qualitative commercial ELISA (97.1\%) and quantitative immunometric ELISA (91.2\%) yielded specificity similar to our observed values (Piechotta et al., 2011).

While ELISA PAG yielded some false positives, this may have attributed to some reasons. One of these could be the late embryonic mortality occurring around 25 days post mating. After pregnancy loss, PAG concentrations will inevitably decrease and disappear. However, because of the long half-life of this protein of approximately eight days (Mialon et al., 1993), the significant drop of PAG in the bloodstream may be delayed, compromising, even subtly, the accuracy of the test. The concentrations of PAG in cows with embryonic mortality are very similar to pregnant cows between 24 and 35 days, which makes it difficult to predict early onset of embryonic loss and to maintain the high accuracy of the early pregnancy tests (Szenci et al., 2000).

Another possibility is related to late luteolysis, since the presence of PAG is associated with the presence of the corpus luteum (Humblot, 2001). According to this author, because of luteal maintenance, about 20 to $30 \%$ of non-pregnant females have detectable PAG concentrations at 24 days post AI when compared to pregnant cows, increasing the number of false positives. Antiluteolitic signals and PAG levels are related at the beginning of gestation since both proteins are released by the trophoblast cells (Humblot et al., 1988a). Some factors can be speculated in relation to the accuracy of false positive results, as the use of inseminated cows once or twice before the experiment, in other words, a subfertile group of females (Humblot et al., 1988b).

During pregnancy, binucleate cells migrate from the trophoblast tissue to the uterine epithelium and the PAG produced by these cells exert distinct biological functions between the placental tissues (Touzard et al., 2013). This is an active process that requires a healthy trophoblastic tissue, therefore, in cases of uterine infections or other mechanisms that support the maintenance of this tissue, the source of PAG is not maintained and the concentrations decrease allowing for misinterpretations during the diagnosis (Dobson et al., 1993).

PAG ELISA was highly accurate in detecting non-pregnant females, corroborating previous results of $100 \%$ negative predictive value in beef cattle (Green et al., 2009). However, our test was more accurate than a previous test in dairy cattle (94.7\%; Romano and Larson, 2010) and two different ELISA tests (91.7\% and 91.2\%; Piechotta et al., 2011). That could be maybe due to the higher PAG levels in the Zebu females (Mercadante et al., 2013).

In contrast, US negative predictive value on day 25 (54.79\%) was lower than previous findings of $67.5 \%$ on days $26-27$ post-insemination (Szenci et al., 1998). Difficulties in observing the gestational vesicle on day 25 likely contributed to the discrepancy between studies. Supporting this explanation, the negative predictive value for US increased significantly on day $28(86.4 \%)$, when the criterion for positive diagnosis was the presence of allantoic fluid. Nonetheless, we still obtained an inferior outcome compared with a previous US examination on day 28 post-TAI, which was $100 \%$ accurate in identifying non-pregnant cattle (Gradela et al., 2009). We believe the fluid amount inside the uterine lumen increased diagnosis difficulty and explains the high percentage of false negatives in our US tests, especially on day 25. Alternatively, embryos in some cows might be positioned behind endometrial folds (DesCôteaux et al., 2009), making them impossible to detect using US.

\section{Conclusions}

We demonstrated that the PAG ELISA technique is highly sensitive, specific, and accurate in early pregnancy diagnoses of Bos indicus beef cattle. Furthermore, PAG ELISA has a major advantage over methods such as US and transrectal palpation, considering the efficiency of the techniques, the time interval service - pregnancy diagnosis, and absence of manipulation of the uterus. Thus, we suggest that this method can be used safely to ascertain gestation status in Zebu cows, beginning from day 25 after mating.

\section{Conflict of interest}

The authors declare that they have no conflict interest.

\section{Supplementary materials}

Supplementary material associated with this article can be found, in the online version, at doi:10.1016/j.livsci.2018.06.018.

\section{References}

Ayres, H., Ferreira, R.M., Torres-Júnior, J.R.S., Demétrio, C.G.B., de Lima, C.G., Baruselli, P.S., 2009. Validation of body condition score as a predictor of subcutaneous fat in Nelore (Bos indicus) cows. Livest. Sci. 123, 175-179.

Barros, B.J.P., Visintin, J.A., 2001. Controle ultra-sonográfico de gestações, de mortalidades embrionárias e fetais e do sexo de fetos bovinos zebuínos. Braz. J. Vet. Res. Anim. Sci. 38, 74-79.

Commun, L., Velek, K., Barbry, J.B., Pun, S., Rice, A., Mestek, A., Egli, C., Leterme, S, 2016. Detection of pregnancy-associated glycoproteins in milk and blood as a test for early pregnancy in dairy cows. J. Vet. Diagn. Invest. 28 (3), 207-213.

de Sousa, N.M., Zongo, M., Pitala, W., Boly, H., Sawadogo, L., Sanon, M., Figueiredo, J.R., Goncalves, P.B.D., El Amiri, B., Perènyi, Z., Beckers, J.F., 2003. Pregnancy-associated glycoprotein concentrations during pregnancy and the postpartum period in Azawak Zebu cattle. Theriogenology 59, 1131-1142.

DesCôteaux, L., Gnemmi, G., Colloton, C., 2009. Ultrasonography of bovine female genital tract. Vet. Clin. North Am. Food Anim. Pract 25, 733-752.

Dobson, H., Rowan, T.G., Kippax, I.S., Humblot, P., 1993. Assessment of fetal number, and fetal and placental viability throughout pregnancy in cattle. Theriogenology 40 , $411-425$.

Garbayo, J.M., Serrano, B., Lopez-Gatius, F., 2008. Identification of novel pregnancyassociated glycoproteins (PAG) expressed by the peri-implantation conceptus of domestic ruminants. Anim. Reprod. Sci. 103, 120-134.

Gradela, A., Danieli, T., Carneiro, T., Torres, D.V., Gradela, C.R., Franzo, V.S., 2009. 
Exatidão da ultra-sonografia para diagnóstico de gestação aos 28 dias após inseminação e sua contribuição na eficiência reprodutiva em fêmeas Nelore e cruzadas. Rev. Port. Ciên. Vet. 104, 31-35.

Green, J.A., Parks, T.E., Avalle, M.P., Telugu, B.P., McLain, A.L., Peterson, A.J., McMillan, W., Mathialagan, N., Hook, R.R., Xie, S., Roberts, R.M., 2005. The establishment of an ELISA for the detection of pregnancy-associated glycoproteins (PAGs) in the serum of pregnant cows and heifers. Theriogenology 63, 1481-1503.

Green, J.C., Volkmann, D.H., Poock, S.E., McGrath, M.F., Ehrhardt, M., Moseley, A.E., Lucy, M.C., 2009. Technical note: A rapid enzyme-linked immunosorbent assay blood test for pregnancy in dairy and beef cattle. J. Dairy Sci. 92, 3819-3824.

Green, J.C., Newsom, E.M., Lucy, M.C., 2011. Incorporation of a rapid pregnancy-associated glycoprotein ELISA into a CIDR-Ovsynch resynchronization program for a 28 day re-insemination interval. Theriogenology 75, 320-328.

Humblot, P., Camous, S., Martal, J., Charlery, J., Jeanguyot, N., Thibier, M., Sasser, G. 1988a. Pregnancy-specific protein B, progesterone concentrations and embryonic mortality during early pregnancy in dairy cows. J. Reprod. Fert. 83, 215-223.

Humblot, P., Camous, S., Martal, J., Charlery, J., Jeanguyot, N., Thibier, M., Sasser, G., 1988b. Diagnosis of pregnancy by radioimumunoassay of a pregnancy-specific protein in the plasma of dairy cows. Theriogenology 30 (2), 257-267.

Humblot, P., 2001. Use of pregnancy specific proteins and progesterone assays to monitor pregnancy and determine the timing, frequencies and sources of embryonic mortality in ruminants. Theriogenology 56, 1417-1433.

Karen, A.M., Darwish, S., Ramoun, A., Tawfeek, K., Hanh, N.V., de Sousa, N.M., Sulon, J., Szenci, O., Beckers, J.F., 2011. Accuracy of transrectal palpation for early pregnancy diagnosis in Egyptian buffaloes. Trop. Anim. Health Prod. 43, 5-7.

Karen, A., de Sousa, N.M., Beckers, J.F., Bajcsy, A.C., Tibold, J., Mádl, I., Szenci, O., 2015. Comparison of a commercial bovine pregnancy-associated glycoprotein ELISA test and a pregnancy-associated glycoprotein radiomimmunoassay test for early pregnancy diagnosis in dairy cattle. Anim. Reprod. Sci. 159, 31-37.

Mercadante, P.M., Waters, K.M., Mercadante, V.R.G., Lamb, G.C., Elzo, M.A., Johnson, S.E., Rae, D.O., Yelich, J.V., Ealy, A.D., 2013. Subspecies differences in early fetal development and plasma pregnancy-associated glycoprotein concentrations in cattle. J. Anim. Sci. 91, 3693-3701.

Mialon, M.M., Camous, S., Renand, G., Martal, J., Ménissier, F., 1993. Peripheral concentrations of a $60-\mathrm{kDa}$ pregnancy serum protein during gestation and after calving and in relationship to embryonic mortality in cattle. Reprod. Nutr. Dev. 33, 269-282.

Piechotta, M., Bollwein, J., Friedrich, M., Heilkenbrinker, T., Passavant, C., Branen, J., Sasser, G., Hoedemaker, M., Bollwein, H., 2011. Comparison of commercial ELISA blood tests for early pregnancy detection in dairy cows. J. Reprod. Dev. 57 (1), $72-75$.

Real, L.M.M., Valencia, G.L., Corral, A., Rentenia, T., 2006. Evaluation of ultrasound for pregnancy diagnosis between 20 and 40 days post insemination in dairy cows. J. Ani. Vet. Adv. 5 (11), 949-951.
Ribeiro, E.S., Galvão, K.N., Thatcher, W.W., Santos, J.E.P., 2012. Economic aspects of applying reproductive technologies to dairy herds. Anim. Reprod 9 (3), 370-387.

Ricci, A., Carvalho, P.D., Amundson, M.C., Fourdraine, R.H., Vincenti, L., Fricke, P.M., 2015. Factors associated with pregnancy-associated glycoprotein (PAG) levels in plasma and milk of Holstein cows during early pregnancy and their effect on the accuracy of pregnancy diagnosis. J. Dairy Sci. 98, 1-13.

Roberts, J.N., Byrem, T.M., Grooms, D.L., 2015. Application of an ELISA milk pregnancy test in beef cows. Reprod. Dom. Anim. 50, 651-658.

Romano, J.E., Thompson, J.A., Forrest, D.W., Westhusin, M.E., Tomaszweski, M.A., Kraemer, D.C., 2006. Early pregnancy diagnosis by transrectal ultrasonography in dairy cattle. Theriogenology 66, 1034-1041.

Romano, J.E., Larson, J.E., 2010. Accuracy of pregnancy specific protein-B test for early pregnancy diagnosis in dairy cattle. Theriogenology 74, 932-939.

Sá Filho, M.F., Baldrighi, J.M., Sales, J.N.S., Crepaldi, G.A., Carvalho, J.B.P., Bó, G.A., Baruselli, P.S., 2011. Induction of ovarian follicular wave emergence and ovulation in progestin-based time artificial insemination protocols for Bos indicus cattle. Anim. Reprod. Sci. 129, 132-139.

Shahin, M., Friedrich, M., Gauly, M., Holtz, W., 2014. Pregnancy-associated glycoprotein (PAG) profile of Holstein-Friesan cows as compared to dual-purpose and beef cows. Reprod. Dom. Anim. 49, 618-620.

Silva, E., Sterry, R.A., Kolb, D., Mathialagan, N., McGrath, M.F., Ballam, J.M., Fricke, P.M., 2007. Accuracy of a pregnancy associated glycoprotein ELISA to determine pregnancy status of lactating dairy cows twenty-seven days after timed artificial insemination. J. Dairy Sci. 90, 4612-4622.

Sinedino, L.D.P., Lima, F.S., Bisinotto, R.S., Cerri, R.L.A., Santos, J.E.P., 2014. Effect of early or late resynchronization based on different methods of pregnancy diagnosis on reproductive performance of dairy cows. J. Dairy Sci. 97, 1-10.

Szenci, O., Gyulai, G.Y., Nagy, P., Kovács, L., Varga, J., Taverne, M.A.M., 1995. Effect of uterus position relative to the pelvic inlet on the accuracy of early bovine pregnancy diagnosis by means of ultrasonography. Vet. Q. 17, 37-39.

Szenci, O., Beckers, J.F., Humblot, P., Sulon, J., Sasser, G., Taverne, M.A.M., Varga, J., Baltusen, R., Schekk, G., 1998. Comparison of ultrasonography, bovine pregnancyspecific protein B, and bovine pregnancy-associated glycoprotein 1 tests for pregnancy detection in dairy cows. Theriogenology 50, 77-88.

Szenci, O., Humblot, P., Beckers, J.F., Sasser, G., Sulon, J., Baltusen, R., Varga, J., Bajcsy, CS.A., Taverne, M.A.M., 2000. Plasma profiles of progesterone and conceptus proteins in cows with spontaneous embryonic/fetal mortility as diagnosed by ultrasonography. Veter. J. 159, 287-290.

Touzard, E., Reinaud, P., Dubois, O., Guyader-Joly, C., Humblot, P., Ponsart, C., Charpigny, G., 2013. Specific expression patterns and cell distribution of ancient and modern PAG in bovine placenta during pregnancy. Reproduction 146, 347-362.

Wallace, R.M., Pohler, K.G., Smith, M.F., Green, J.A., 2015. Placental PAGs: gene origins, expression patterns, and use as markers of pregnancy. Reproduction 149, 115-126. 